\title{
Evaluation of Sources of Nitrate Beneath Food Processing Wastewater-Application Sites near Umatilla, Oregon
}

Scientific Investigations Report 2009-5069 
This page intentionally left blank. 


\section{Evaluation of Sources of Nitrate Beneath Food Processing Wastewater-Application Sites near Umatilla, Oregon}

By Lonna Frans and Anthony Paulson, U.S. Geological Survey;

Phil Richerson, Oregon Department of Environmental Quality;

Elise Striz and Curt Black, U.S. Environmental Protection Agency

Scientific Investigations Report 2009-5069 


\section{U.S. Department of the Interior \\ KEN SALAZAR, Secretary \\ U.S. Geological Survey \\ Suzette M. Kimball, Acting Director}

U.S. Geological Survey, Reston, Virginia: 2009

For more information on the USGS - the Federal source for science about the Earth, its natural and living resources, natural hazards, and the environment, visit http://www.usgs.gov or call 1-888-ASK-USGS

For an overview of USGS information products, including maps, imagery, and publications, visit http://www.usgs.gov/pubprod

To order this and other USGS information products, visit http://store.usgs.gov

Any use of trade, product, or firm names is for descriptive purposes only and does not imply endorsement by the U.S. Government.

Although this report is in the public domain, permission must be secured from the individual copyright owners to reproduce any copyrighted materials contained within this report.

Suggested citation:

Frans, Lonna, Paulson, Anthony, Richerson, Phil, Striz, Elise, and Black, Curt, 2009, Evaluation of sources of nitrate beneath food processing wastewater-application sites near Umatilla, Oregon: U.S. Geological Survey Scientific Investigations Report 2009-5069, 14 p. 


\section{Contents}

Abstract
Introduction
Site Descriptions
Methods
Nitrate at Wastewater-Application Sites
Serrace Farm Site
References Farm Site

\section{Figures}

Figure 1. Map showing locations of the North Farm and Terrace Farm study sites in the Umatilla River basin, Oregon

Figure 2. Map and cross section showing locations of $(A)$ ground-water contours and flow direction and $(B)$ depths to water, nitrate concentrations, and apparent recharge age at selected wells, Terrace Farm site, Umatilla River basin, Oregon

Figure 3. Graph showing ratios of delta hydrogen-2 $\left(\delta^{2} \mathrm{H}\right)$ and delta oxygen-18 $\left(\delta^{18} 0\right)$ for water samples from wells in the North Farm and Terrace Farm sites, Umatilla River basin, Oregon

Figure 4. Graphs showing relations between $(A)$ sulfate-chloride and $(B)$ calcium-delta oxygen-18 $\left(\delta^{18} 0\right)$ for water samples from wells, Terrace Farm site Umatilla River basin, Oregon

Figure 5. Graph showing ratios of delta oxygen-18 $\left(\delta^{18} 0\right)$ and delta nitrogen-15 $\left(\delta^{15} \mathrm{~N}\right)$ for nitrates in samples compared with the range of ratios expected for different sources of nitrate, Umatilla River basin, Oregon....

Figure 6. Graph showing relation between nitrate delta nitrogen-15 $\left(\delta^{15} \mathrm{~N}\right)$ and delta oxygen-18 $\left(\delta^{18} 0\right)$ isotope ratios and fraction of water samples from wells, Terrace Farm site, Umatilla River basin, Oregon

Figure 7. Map and cross sections showing locations of $(A)$ ground-water elevation contours and flow direction and $(B)$ depths to ground water, nitrate concentrations, and apparent recharge age at selected wells, North Farm site, Umatilla River basin, Oregon

Figure 8. Trilinear diagram showing cations for North Farm site water samples from wells, Columbia River water, and process water from the wastewater-plant clarifier, Umatilla River basin, Oregon

Figure 9. Graph showing relation of sulfate and calcium from water samples from wells at the North Farm site, Columbia River water, and process water from the wastewater-plant clarifier, Umatilla River basin, Oregon

Figure 10. Graph showing relations between delta oxygen-18 $\left(\delta^{18} 0\right)$ and delta nitrogen-15 $\left(\delta^{15} \mathrm{~N}\right)$ of nitrate from water samples from wells, North Farm site, Umatilla River basin, Oregon 


\section{Tables}

Table 1. Selected chemical and isotopic analyses and proportions of water attributed to each end-member at the North Farm and Terrace Farm sites, Umatilla River basin, Oregon

Table 2. Difference of cations and anions in water from wells at the Terrace Farm site, Umatilla River basin, Oregon

Table 3. Slope, intercept, and $R^{2}$ value for EMMA-predicted versus actual concentrations at the Terrace Farm site, Umatilla River basin, Oregon

Table 4. Difference of cations and anions in water from well MW-10 compared to wells MW-3, $-4,-33$ and $11-3$ and -4 at the North Farm site, Umatilla River basin, Oregon

\section{Conversion Factors, Datum, and Abbreviations and Acronyms}

Conversion Factors

\begin{tabular}{lcl}
\hline \multicolumn{1}{c}{ Multiply } & By & \multicolumn{1}{c}{ To obtain } \\
\hline & Length & \\
\hline centimeter $(\mathrm{cm})$ & 0.3937 & inch (in.) \\
kilometer $(\mathrm{km})$ & 0.6214 & mile (mi) \\
meter $(\mathrm{m})$ & 3.281 & foot $(\mathrm{ft})$ \\
meter $(\mathrm{m})$ & 1.094 & yard (yd) \\
\hline & Volume & \\
\hline liter $(\mathrm{L})$ & 0.2642 & gallon (gal) \\
cubic meter $\left(\mathrm{m}^{3}\right)$ & 264.2 & gallon (gal) \\
cubic meter $\left(\mathrm{m}^{3}\right)$ & 35.31 & cubic foot (ft $\left.{ }^{3}\right)$ \\
cubic meter $\left(\mathrm{m}^{3}\right)$ & 0.0008107 & acre-foot (acre-ft) \\
\hline
\end{tabular}

Concentrations of chemical constituents in water are given either in milligrams per liter (mg/L) or micrograms per liter $(\mu \mathrm{g} / \mathrm{L})$.

Datum

Vertical coordinate information is referenced to the North American Vertical Datum of 1988 (NAVD 88). 


\title{
Conversion Factors, Datum, and Abbreviations and Acronyms-Continued
}

\author{
Abbreviations and Acronyms \\ $\delta^{15} \mathrm{~N} \quad$ delta nitrogen-15 \\ $\delta^{18} 0 \quad$ delta oxygen-18 \\ $\%$ parts per thousand \\ $\delta^{2} \mathrm{H} \quad$ delta hydrogen-2 \\ ${ }^{3} \mathrm{H} /{ }^{3} \mathrm{He} \quad$ ratio of hydrogen-3 to helium-3 \\ ${ }^{3} \mathrm{H} \quad$ hydrogen-3 \\ ${ }^{3} \mathrm{He} \quad$ helium-3 \\ $\delta^{3} \mathrm{He} \quad$ delta helium-3 \\ ${ }^{4} \mathrm{He} \quad$ helium-4 \\ $\mathrm{N}_{2} \quad$ nitrogen gas \\ $\mathrm{Ne}$ neon \\ $\mathrm{NH}_{4} \quad$ ammonium \\ $\mathrm{NO}_{3} \quad$ nitrogen \\ $\mathrm{mm} \quad$ micrometer \\ EMMA End-member mixing analysis \\ PCA principal component analysis \\ SLAP Standard Light Antarctic Precipitation \\ USEPA U.S. Environmental Protection Agency \\ VSMOW Vienna Standard Mean Ocean Water
}


This page intentionally left blank. 


\title{
Evaluation of Sources of Nitrate Beneath Food Processing Wastewater-Application Sites near Umatilla, Oregon
}

\author{
By Lonna Frans ${ }^{1}$, Anthony Paulson', Phil Richerson'2, Elise Striz ${ }^{3}$, and Curt Black ${ }^{3}$
}

\section{Abstract}

Water samples from wells were collected beneath and downgradient of two food-processing wastewater-application sites near Umatilla, Oregon. These samples were analyzed for nitrate stable isotopes, nutrients, major ions, and agedating constituents to determine if nitrate-stable isotopes can be used to differentiate food-processing waste from other potential sources of nitrate. Major-ion data from each site were used to determine which samples were associated with the recharge of the food-processing wastewater. End-member mixing analysis was used to determine the relative amounts of each identified end member within the samples collected from the Terrace Farm site. The delta nitrogen-15 $\left(\delta^{15} \mathrm{~N}\right)$ of nitrate generally ranged between +2 and +9 parts per thousand and the delta oxygen-18 $\left(\delta^{18} \mathrm{O}\right)$ of nitrate generally ranged between -2 and -7 parts per thousand. None of the samples that were determined to be associated with the wastewater were different from the samples that were not affected by the wastewater. The nitrate isotope values measured in this study are also characteristic of ammonium fertilizer, animal and human waste, and soil nitrate; therefore, it was not possible to differentiate between food-processing wastewater and the other nitrate sources. Values of $\delta^{15} \mathrm{~N}$ and $\delta^{18} \mathrm{O}$ of nitrate provided no more information about the sources of nitrate in the Umatilla River basin than did a hydrologic and geochemical understanding of the ground-water system derived from interpreting water-level and major-ion chemistry data.

\footnotetext{
${ }^{1}$ U.S. Geological Survey

${ }^{2}$ Oregon Department of Environmental Quality

${ }^{3}$ U.S. Environmental Protection Agency
}

\section{Introduction}

Stable isotopes of nitrate have been used for more than 30 years to determine nitrate sources in water supplies (Kohl and others, 1971; Kreitler, 1975; Kreitler and Jones, 1975; Kreitler and others, 1978; Gormly and Spalding, 1979; Kreitler, 1979; Wolterink and others, 1979; Mariotti and others, 1980; Spalding and others, 1982; Heaton and others, 1983; Kreitler and Browning, 1983; Flipse and others, 1984; Heaton, 1984; Mariotti and others, 1984; Exner and Spalding, 1985; Flipse and Bonner, 1985; Heaton, 1986; Hubner, 1986; Amberger and Schmidt, 1987; Mariotti and others, 1988; Aravena and others, 1993; Komor and Anderson, 1993; Clark and Fritz, 1997; Aravena and Robertson, 1998). Although the delta oxygen-18 $\left(\delta^{18} \mathrm{O}\right)$ and delta nitrogen-15 $\left(\delta^{15} \mathrm{~N}\right)$ of nitrate derived from various nitrate sources, including nitrate and ammonium fertilizers, soil nitrogen, precipitation, and manure and septic waste, are known (Kendall, 1998), values from nitrate derived from food-processing wastewater applications have not been published.

Food-processing activities related to french-fry production generate large volumes of nutrient-rich wastewater on a daily basis (Grondin and Camacho, 1995). Foodprocessing wastewater often is applied as a treatment/ disposal method to crop land in the study area in north-central Oregon near Umatilla. Since the early 1980s, more than 1 million pounds of nitrogen have been produced annually by food-processing activities in the Umatilla River basin. These activities are a potential source of nitrate to the groundwater system of the basin. The objective of this study was to measure the $\delta^{15} \mathrm{~N}$ and $\delta^{18} \mathrm{O}$ of nitrate in ground water beneath food-processing wastewater application sites in the Umatilla River basin to determine if the nitrate resulting from the foodprocessing wastewater-application could be distinguished from other potential sources of nitrate. 


\section{Site Descriptions}

Two food-processing wastewater-application sites in the Umatilla River basin study area in north-central Oregon were studied (fig. 1): the Terrace Farm site and the North Farm site. At both sites, a shallow, unconfined aquifer occurs in the alluvial sediment that overlies the Columbia River Basalt Group; the sediment comprises primarily silt, sand, and gravel that resulted from the floods of glacial Lake Missoula (Wozniak, 1995). The aquifer mainly consists of basaltic fragments of plagioclase, pyroxene, and volcanic glass. Secondary minerals, such as calcite, smectite, gypsum, and dolomite, occur as well. The ground-water chemistry is generally classified as a mixed-cation/bicarbonate type (Grondin and Nelson, 1995).

The Terrace Farm site is on an upland terrace between Emigrant Buttes to the east and the Butter Creek flood plain to the west (Richerson, 2004). The Hunt Irrigation Ditch runs along the western and northern edges of the site. Foodprocessing wastewater had been applied to the site since 1981 on what previously was dryland and then irrigated farmland. Irrigated agriculture is the dominant land use upgradient of the Terrace Farm site. Immediately downgradient of the Terrace Farm site is a cattle-feedlot that has been in operation since before 1985. Columbia River water is the source of the process water for the Terrace Farm site.

The North Farm site is on a northeast/southwest trending topographic ridge that includes rangeland areas surrounding a landfill in the northwest section, the Umatilla Ordnance Depot to the west, and the North Farm wastewater-application areas to the east. Food-processing wastewater has been applied to the North Farm site since 1972 on land that previously was dryland (Richerson, 2004). The Umatilla Ordnance Depot landfill began accepting solid waste (mostly packing material) in 1968 and ceased receiving waste in 1993. Some munitionscontaminated soils that were solidified with cement were placed in the landfill in 1994. A slight downward vertical gradient generally has been observed beneath the wastewater application area (Phil Richerson, Oregon Department of Environmental Quality, written commun., September 2005), which is consistent with recharge occurring due to the wastewater application. The vertical gradient on the western edge of the wastewater-application area, however, occasionally reverses itself indicating that there are brief periods of upward movement of water at that location.

Food-processing wastewater, characterized by high levels of total Kjeldahl nitrogen (greater than $100 \mathrm{mg} / \mathrm{L}$ ) and low amounts of nitrate (about $1 \mathrm{mg} / \mathrm{L}$ ), was being applied to the two sites at the time of the study in 2004. The wastewater is sprayed on the crops by using center pivot sprinkler systems during the crop growing season, which typically runs from March through October. Various crops are grown, including corn, wheat, alfalfa, barley, forage grasses, potatoes, and peas.

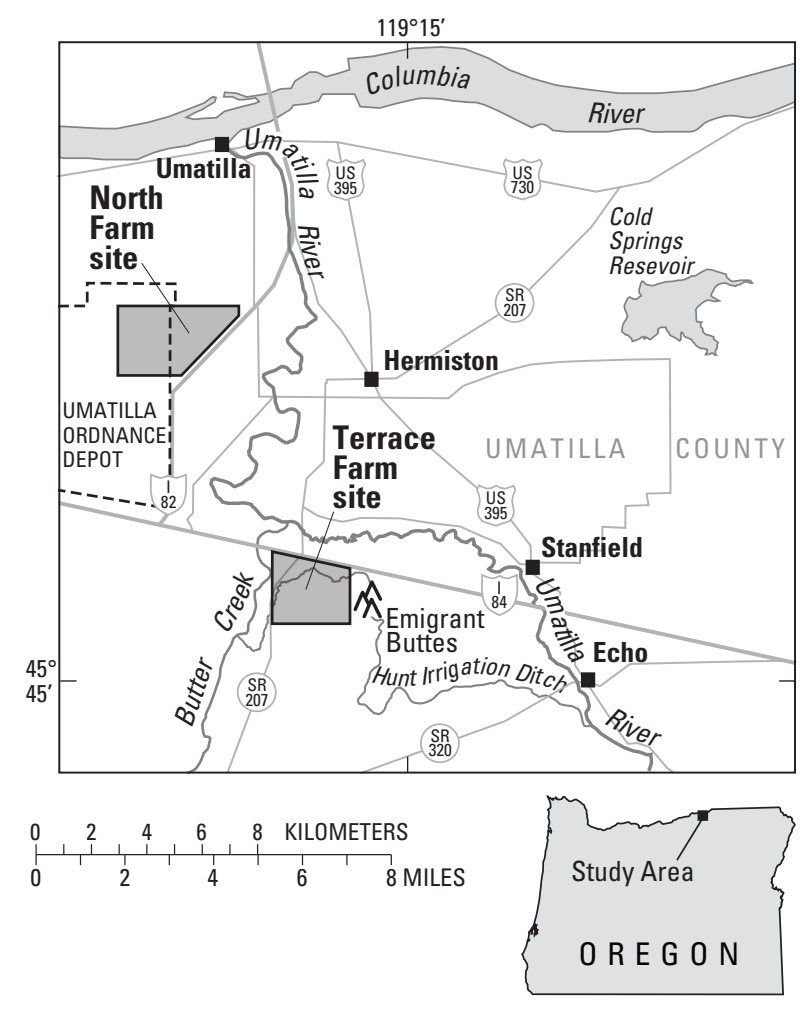

Figure 1. Locations of the North Farm and Terrace Farm study sites in the Umatilla River basin, Oregon.

\section{Methods}

Ground-water levels and samples were collected from the shallow ground water at the Terrace Farm site in August 2004 and at the North Farm site in January and April 2004. Samples were collected from the ground-water system, rather than directly from the process water, because the process water is nitrate poor and the isotopic values of the nitrate would change as the organic nitrogen undergoes nitrification to become nitrate.

Water samples from monitoring wells were collected by using submersible pumps. Each monitoring well had a screen-interval length of $3.0 \mathrm{~m}$, and samples were collected at each well only after at least three casing volumes of water were purged and basic field parameters had stabilized. Water samples were collected from temporary push-probe wells at three Terrace Farm sites (Terrace-1, Terrace-2, and Terrace-3; fig. 2).

Hydrogen-isotope ratios of water were analyzed by isotope-ratio mass spectrometry following hydrogen-water equilibration (Coplen and others, 1991) and are expressed relative to Vienna Standard Mean Ocean Water (VSMOW), 
A.
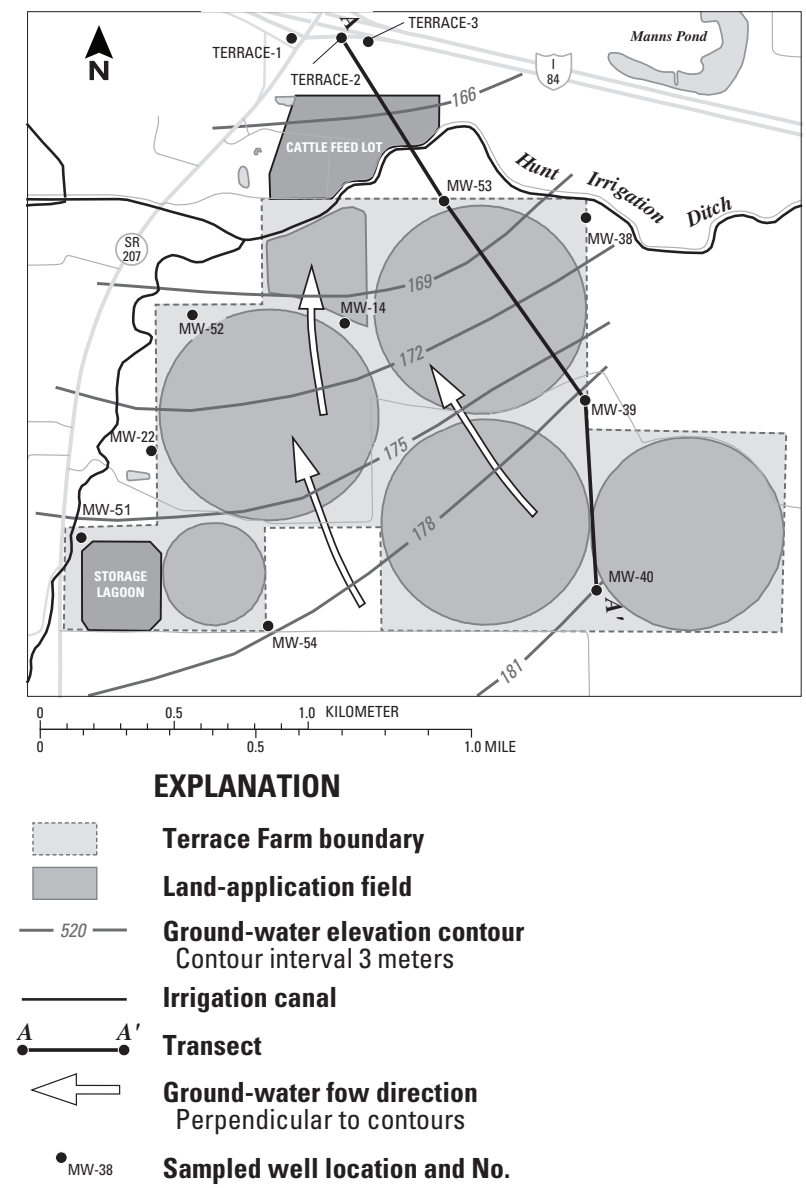

B.

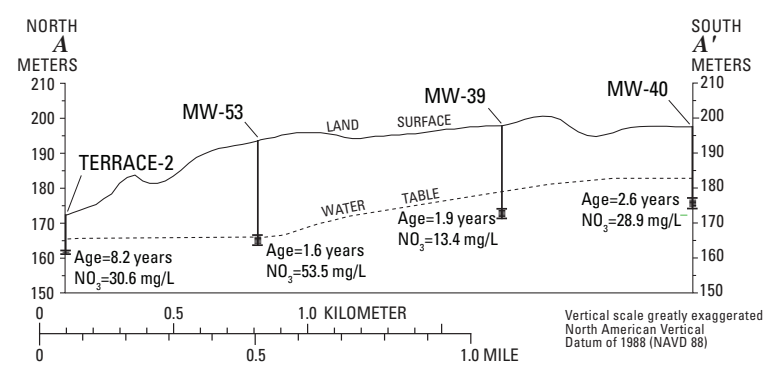

Figure 2. Locations of $(A)$ ground-water contours and flow direction and $(B)$ depths to water, nitrate concentrations, and apparent recharge age at selected wells, Terrace Farm site, Umatilla River basin, Oregon. such that delta-2 hydrogen $\left(\delta^{2} \mathrm{H}\right)$ of Standard Light Antarctic Precipitation (SLAP) reference water is -428 parts per thousand (\%o) (Coplen, 1996). Oxygen-isotope ratios of water were determined by the carbon dioxide-water equilibration (Epstein and Mayeda, 1953) and are expressed relative to VSMOW, such that $\delta^{18} \mathrm{O}$ of SLAP reference water is $-55.5 \%$ (Coplen, 1996).

Samples for hydrogen-3/helium-3 $\left({ }^{3} \mathrm{H} /{ }^{3} \mathrm{He}\right)$ age determination $\left({ }^{3} \mathrm{H}, \delta^{3} \mathrm{He},{ }^{4} \mathrm{He}\right.$, and Ne analyses) were collected in 80-cm-long copper tubes with pinch-off clamps and 500 $\mathrm{mL}$ plastic bottles, and analyzed by using mass-spectrometric procedures (Ekwurzel and others, 1994; Ludin and others, 1998) at the Noble Gas Laboratory, Lamont-Doherty Earth Observatory, of Columbia University, Palisades, New York. Gases were extracted from the water samples in the copper sample tubes by using a vacuum extraction line and were transferred into flame-sealed glass ampoules. After separation of water vapor and dissolved gases into several cryogenic traps, He isotopes were measured on a VG 5400 mass spectrometer. After release from the cryogenic trap, neon was measured in a quadrupole mass spectrometer. The gas-free water sample was flame-sealed in a glass bulb, and after about 6 months, the tritiogenic ${ }^{3} \mathrm{He}$ was extracted from the glass bulb and measured using a mass spectrometer. The ratio of ${ }^{3} \mathrm{H} /$ tritiogenic ${ }^{3} \mathrm{He}$ then was used to calculate the apparent recharge age of the water (Schlosser and others., 1988, 1989).

Unfiltered samples were analyzed for concentrations of nutrients and major ions by the U.S. Environmental Protection Agency (USEPA) Manchester Environmental Laboratory in Port Orchard, Washington. Samples for the analysis of nitrite-plus-nitrate, ammonia, and phosphate were preserved with sulfuric acid and analyzed by using USEPA Methods 353.2, 350.1, and 365.1, respectively (U.S. Environmental Protection Agency, 1993). Samples for the analyses of magnesium, calcium, potassium, and sodium were preserved with nitric acid ( $\mathrm{pH}$ less than 2) and analyzed by using USEPA Method 200.7 (U.S. Environmental Protection Agency, 1991). Samples for the analysis of chloride and sulfate were untreated and were analyzed using USEPA method 300.0 (U.S. Environmental Protection Agency, 1993). Filtered water (0.45 $\mu \mathrm{m}$ ) was analyzed for isotope ratios of nitrogen and oxygen in dissolved nitrate by bacterial conversion of nitrate to nitrous oxide and subsequent measurement on a continuous-flow isotope-ratio mass spectrometer at the U.S. Geological Survey (USGS) Stable Isotope Laboratory (Sigman and others, 2001; Casciotti and others, 2002; Revesz and Casciotti, 2003). Nitrogen-isotope ratios were reported in parts per thousand relative to nitrogen gas $\left(\mathrm{N}_{2}\right)$ in air (Mariotti, 1983). Oxygenisotopes of nitrate were expressed in the same manner as those 
of water and were corrected for drift, blank, and exchange with water by using USGS 34 and USGS 35 (Böhlke and others, 2004). Data from field and laboratory measurements for sites listed in table 1 are available at http://waterdata.usgs. gov/wa/nwis/qw. Major ions and nutrient results from samples collected from the Umatilla Ordnance Depot landfill wells on the North Farm site were obtained from SCS Engineers (Mark Varljen, SCS Engineers, written commun., November 2004).

End-member mixing analysis (EMMA) (Christophersen and Hooper, 1992) was used to estimate the water contribution to each well sample from the various end members determined at each site. The EMMA model was developed by: (1) constructing constituent-constituent plots to estimate the number of identifiable end members present at each site and the representative solute concentrations of each end member; (2) completing a principal component analysis (PCA) (SAS Institute, 1990) for various constituent combinations; (3) selecting constituents with the largest proportion of variance explained by the first two components for the end-member mixing analysis; (4) determining the proportions of each end member in each well sample by using a Microsoft EXCEL spreadsheet (available at www.cof.orst.edu/cof/fe/watershd/ Documents/Shortcourses/shortcourse/EMMA.xls; and (5) comparing the concentrations predicted by EMMA with the measured concentrations by using linear regression.

Table 1. Selected chemical and isotopic analyses and proportions of water attributed to each end-member at the North Farm and Terrace Farm sites, Umatilla River basin, Oregon.

[Abbreviations: USGS, U.S. Geological Survey; m, meter; mg/L, milligram per liter; \%o, per mil; -, not determined; NA, not available; >, greater than]

\begin{tabular}{|c|c|c|c|c|c|c|c|c|c|c|c|}
\hline \multirow[b]{2}{*}{$\begin{array}{l}\text { USGS station } \\
\text { No. }\end{array}$} & \multirow[b]{2}{*}{$\begin{array}{l}\text { Well } \\
\text { identifi- } \\
\text { cation } \\
\text { No. }\end{array}$} & \multirow[b]{2}{*}{$\begin{array}{l}\text { Elevation } \\
\text { of water } \\
\text { table (m) }\end{array}$} & \multirow[b]{2}{*}{$\begin{array}{l}\text { Top of } \\
\text { screen in } \\
\text { relation } \\
\text { to water } \\
\text { level (m) }\end{array}$} & \multirow[b]{2}{*}{$\begin{array}{c}\mathrm{NO}_{3} \\
\text { (mg/L) }\end{array}$} & \multirow[b]{2}{*}{$\begin{array}{l}\delta^{15} N \\
(\%)\end{array}$} & \multirow[b]{2}{*}{$\begin{array}{l}\delta^{18} 0 \\
(\%)\end{array}$} & \multirow[b]{2}{*}{$\begin{array}{l}\text { Tritium } \\
\text { (TU) }\end{array}$} & \multirow[b]{2}{*}{$\begin{array}{l}\text { Recharge } \\
\text { age } \\
\text { (years) }\end{array}$} & \multicolumn{3}{|c|}{$\begin{array}{c}\text { Proportion of water from each end } \\
\text { member }\end{array}$} \\
\hline & & & & & & & & & $\begin{array}{l}\text { Upgradient } \\
\text { ground } \\
\text { water }\end{array}$ & $\begin{array}{c}\text { Western } \\
\text { ground water } \\
\text { affected by } \\
\text { irrigation } \\
\text { canal leakage }\end{array}$ & $\begin{array}{c}\text { Terrace } \\
\text { Farm } \\
\text { water }\end{array}$ \\
\hline 454625119192101 & MW-14 & 170.5 & -7.7 & 41.5 & 4.87 & -3.82 & 0.05 & 48.9 & 0.11 & 0.89 & 0.00 \\
\hline 454604119195501 & MW-22 & 173.9 & - & 30.1 & 4.49 & -3.01 & - & - & .01 & .99 & .00 \\
\hline 454636119184101 & MW-38 & 171.6 & .5 & 14.7 & 3.54 & -2.91 & - & - & .64 & .31 & .05 \\
\hline 454612119184101 & MW-39 & 179.2 & -4.8 & 13.4 & 7.55 & -5.80 & .92 & 1.9 & 1.00 & .00 & .00 \\
\hline 454546119181401 & MW-40 & 181.2 & -3.9 & 28.9 & 8.51 & -5.99 & .43 & 2.6 & .92 & .08 & .00 \\
\hline 454551119201001 & MW-51 & 176.4 & .6 & 9.95 & 4.39 & -2.16 & - & - & .58 & .00 & .42 \\
\hline 454657119192501 & Terrace-2 & 165.8 & -3.4 & 30.6 & 4.62 & -3.25 & 2.8 & 8.2 & .15 & .82 & .03 \\
\hline 454656119190801 & Terrace-3 & 165.9 & -2.5 & 28.2 & 4.56 & -3.42 & - & - & .24 & .72 & .04 \\
\hline \multicolumn{12}{|c|}{ North Farm site } \\
\hline 455128119224901 & MW-3 & 171.9 & -17.1 & 8.58 & 3.40 & -4.08 & - & - & & & \\
\hline 455150119221901 & MW-4 & 172.1 & -17.9 & 25.9 & 4.95 & -3.53 & - & - & & & \\
\hline 455128119224301 & MW-10 1 & 171.6 & -3.1 & 48.0 & 6.27 & -3.06 & 6.7 & 5 & & & \\
\hline 455100119234101 & MW-33 ${ }^{1}$ & 156.8 & -7.7 & 15.4 & 4.20 & -5.40 & .04 & $>50$ & & & \\
\hline 455104119235401 & MW-34 & 155.1 & -5.1 & 13.9 & - & - & - & - & & & \\
\hline 455102119235501 & MW-35 & 154.7 & -2.9 & 10.3 & - & - & - & - & & & \\
\hline 455106119234901 & MW-36 & 156.7 & -5.5 & 14.1 & - & - & - & - & & & \\
\hline 455111119235401 & $11-1$ & 156.3 & -4.0 & 16.6 & - & - & - & - & & & \\
\hline 455040119235701 & $11-10$ & 153.9 & -.7 & 6.29 & 3.07 & -5.39 & - & - & & & \\
\hline
\end{tabular}

\footnotetext{
${ }^{1}$ Nitrate and isotope values are average of January and April samples.
} 


\section{Nitrate at Wastewater-Application Sites}

\section{Terrace Farm Site}

Water levels measured from wells at the Terrace Farm wastewater-application site indicated that ground water generally flows towards the northwest (fig. 2A). Depths to water at the Terrace Farm site ranged from about $15 \mathrm{~m}$ at well MW-40 to $26 \mathrm{~m}$ at well MW-53 and then shallowed to around $8 \mathrm{~m}$ below land surface downgradient of the cattle feedlot (fig. 2B).

Apparent recharge ages ranged from 1.6 to 49 years in water samples from wells in the wastewater-application site and averaged about 8 years for water samples from wells downgradient of the feedlot (fig. 2; table 1). Apparent recharge ages were uncorrected for terrigenic helium because the samples may have been fractionated. The tritium concentration values were consistent with piston flow at several of the wells (Terrace-1, Terrace-2, and MW-53) because the tritium concentration values were about equal to those expected in precipitation for their given recharge year.

Conversely, at wells MW-39 and MW-40, the tritium concentration values indicated a mixture of young and old waters. The $\delta^{18} \mathrm{O}$ and $\delta^{2} \mathrm{H}$ ratios of water sampled from wells were along the local meteoric water line (constructed from samples collected from nearby rivers and streams), indicating that the aquifer water was not notably affected by evaporation (fig. 3).
Constituent-constituent plots that were constructed for relatively conservative ions at the Terrace Farm site indicated that three identifiable, potential end members were present (fig. 4). The end members included a group with low concentrations of sulfate, chloride, and calcium (less than $100 \mathrm{mg} / \mathrm{L}$ ) and low $\delta^{18} \mathrm{O}$ of water; a group with higher concentrations of sulfate, chloride, calcium and slightly higher $\delta^{18} \mathrm{O}$ of water; and Terrace Farm water, which had a high concentration of sulfate, but a low concentration of chloride and a much higher $\delta^{18} \mathrm{O}$ of water. The median concentrations of constituents in water from wells MW-39 and MW-40 were selected to represent the group with lower concentrations of sulfate, chloride, and calcium. This end member likely is representative of the upgradient ground water because these wells generally are on the upgradient side of the study area and away from the irrigation canal. The median concentrations of constituents in water from wells MW-22 and MW-52 were selected to represent the water with higher concentrations of sulfate, chloride, and calcium and slightly higher $\delta^{18} \mathrm{O}$ ratio of water. The source of this end member is unknown, but may be ground water flowing from west of the site, and (or) may be affected by irrigation canal leakage or application of road salt because these wells are screened near the water table and are near the irrigation canal and road. On a molar scale, the largest increase in concentration was for the chloride ion (4.5 millimolar) between wells MW-22 and MW-52 relative to wells MW-39 and MW-40 (table 2). Additionally, the increases in concentrations of calcium, magnesium, alkalinity, and sulfate were not consistent with the dissolution of a combination of carbonate minerals and gypsum. It is unlikely that geochemical reactions with aquifer minerals were responsible for the increases in the concentrations of most major ions in water from wells MW-22 and MW-52.

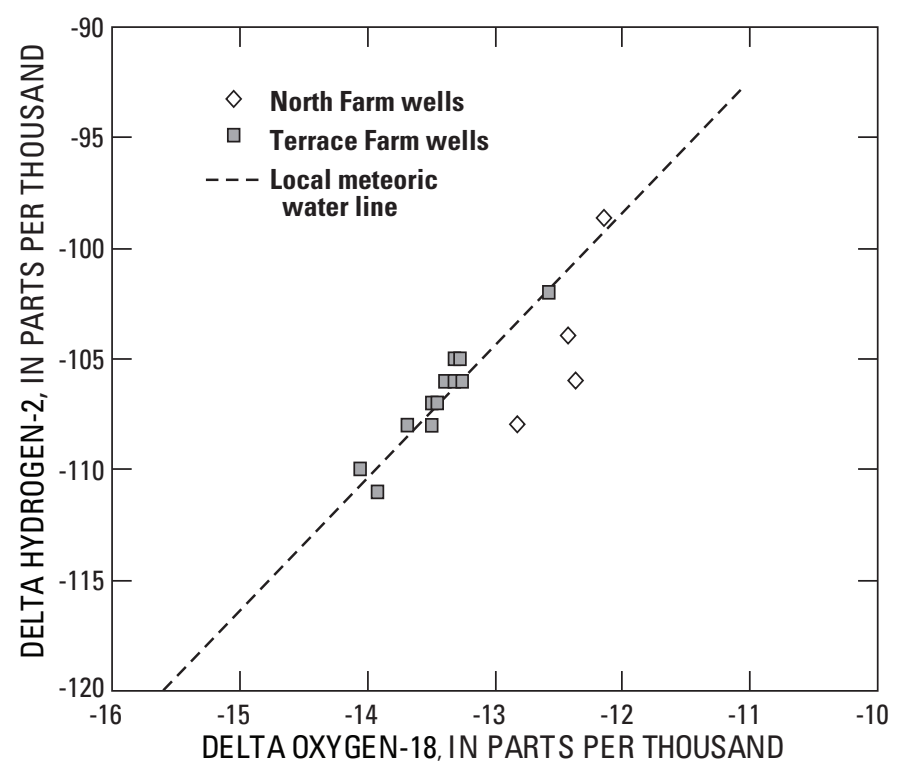

Figure 3. Ratios of delta hydrogen-2 $\left(\delta^{2} \mathrm{H}\right)$ and delta oxygen-18 $\left(\delta^{18} 0\right)$ for water samples from wells in the North Farm and Terrace Farm sites, Umatilla River basin, Oregon. 

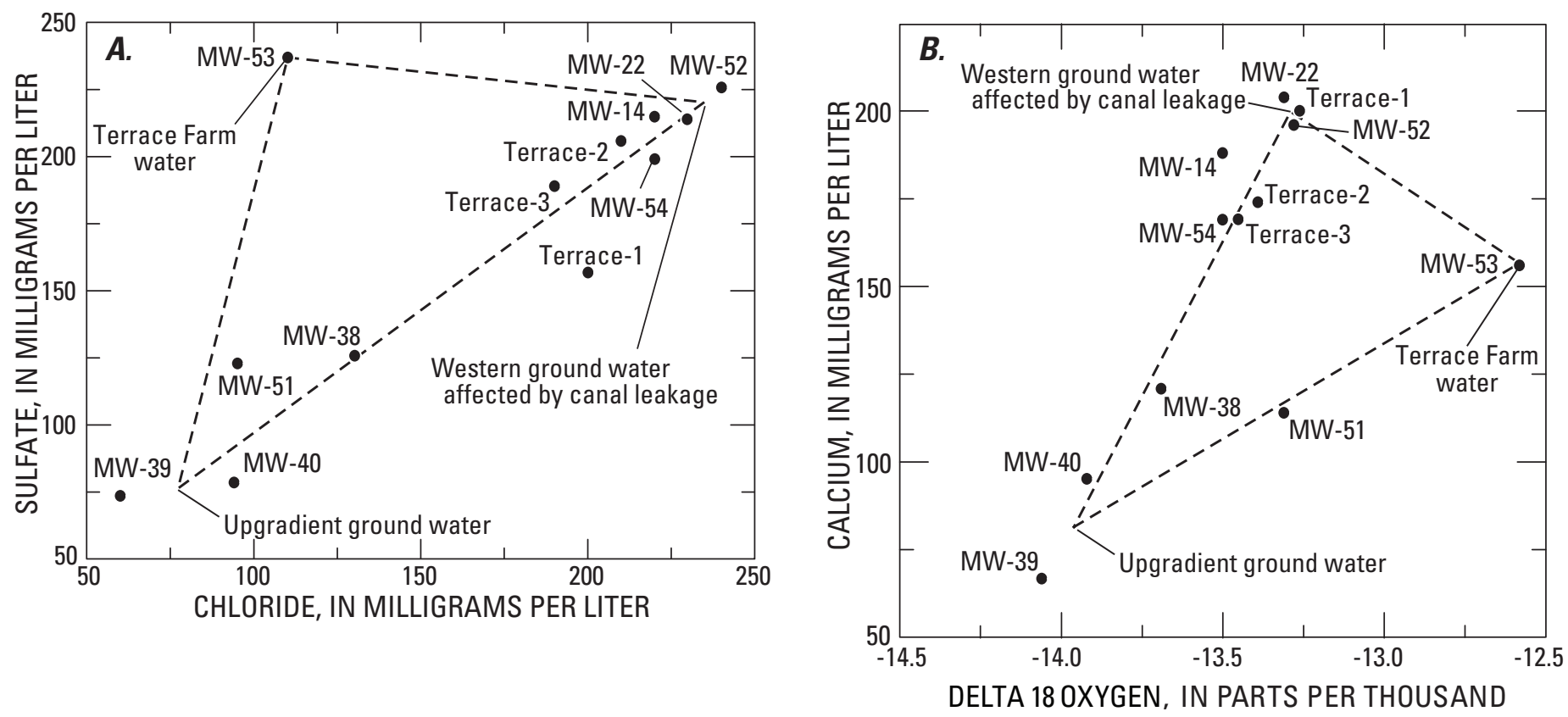

Figure 4. Relations between $(A)$ sulfate-chloride and $(B)$ calcium-delta oxygen-18 $\left(\delta^{18} 0\right)$ for water samples from wells, Terrace Farm site Umatilla River basin, Oregon. (Probable end-members are at the three points of each triangle.)

Table 2. Difference of cations and anions in water from wells at the Terrace Farm site, Umatilla River basin, Oregon.

\begin{tabular}{lcc}
\hline \multicolumn{1}{c}{ Constituent } & $\begin{array}{c}\text { MW-22 and 52 } \\
\text { compared with } \\
\text { MW-39 and 40 }\end{array}$ & $\begin{array}{c}\text { MW-53 } \\
\text { compared with } \\
\text { MW-39 and 40 }\end{array}$ \\
\hline & Cations (millimolars) & \\
\hline Calcium & 2.97 & 1.87 \\
Magnesium & 1.34 & .60 \\
Potassium & .03 & .12 \\
Sodium & .35 & .85 \\
$\quad$ Total milliequivalents & 8.99 & 5.91 \\
\hline & Anions (millimolars) & \\
\hline Alkalinity & 0.70 & -0.42 \\
Chloride & 4.46 & .93 \\
Sulfate & 1.50 & .58 \\
Nitrate & .19 & 4.39 \\
$\quad$ Total milliequivalents & 8.35 & \\
\hline
\end{tabular}

Well MW-53 was selected to represent the Terrace Farm water and because it was geochemically isolated from other wells sampled. The water in well MW-53 likely represents the ground water from the wastewater application on the Terrace Farm, because of its young apparent age, lack of mixing with older waters, and heavier $\delta^{18} \mathrm{O}$ and $\delta^{2} \mathrm{H}$ values, which may indicate recharge during summer when the wastewater is applied. The increase in calcium and sulfate concentrations in water from well MW-53 relative to wells MW-39 and -40 is consistent with the dissolution of about $230 \mathrm{mg} / \mathrm{L}$ of gypsum. Terrace- 1 was excluded from the EMMA because it seemed to be affected by heterogeneity or a possible fourth source of water that may originate from the west side of the study area; Terrace-1 frequently plotted outside the mixing lines for the other three end members.

The PCA selected for use in the EMMA incorporated four constituents (calcium, chloride, sulfate, and $\delta^{18} \mathrm{O}$ of water) for the Terrace Farm site because the first two principal components explained about 99 percent of the variability, and the remaining conservative constituents were strongly correlated with at least one of the four incorporated 
constituents. For each constituent included in the EMMA, the linear-regression relations between the predicted and measured concentrations produced slopes between 0.93 and 1.0 and coefficient of determination $\left(R^{2}\right)$ values between 0.98 and 0.99 (table 3 ). The $R^{2}$ values and slopes close to 1 indicated that the EMMA model is a strong predictor of ground-water concentrations for the conservative solutes. To determine how robust the analysis was, the results from the EMMA also were used to predict concentrations for constituents that were not included in the EMMA. The conservative constituents (magnesium, bromide, and $\delta^{2} \mathrm{H}$ ) had high $R^{2}$ values and slopes near 1 , similar to the constituents that were included in the EMMA. Bicarbonate, nitrate, sodium, and potassium, however, had much lower slopes and $R^{2}$ values, indicating that these constituents probably were nonconservative.

EMMA indicated that most samples included a mixture of water from upgradient and western ground water that was affected by irrigation-canal leakage. A large proportion of water from Terrace Farm (table 1) was inferred by the EMMA only in samples collected from two wells (MW-51 and MW-53). The sample from well MW-51 contained a mix of about 60 percent upgradient ground water and 40 percent Terrace Farm water, which is consistent with its location on

Table 3. Slope, intercept, and $R^{2}$ value for EMMA-predicted versus actual concentrations at the Terrace Farm site, Umatilla River basin, Oregon.

[Abbreviations: EMMA, end-member mixing analysis; $\delta^{18} \mathrm{O}$, delta oxygen- $18 ; \delta^{2} \mathrm{H}$, delta hydrogen-2]

\begin{tabular}{lrcc}
\hline \multicolumn{1}{c}{ Constituent } & Slope & Intercept & $\boldsymbol{R}^{\mathbf{2}}$ \\
\hline Bromide & 0.98 & 0.00 & 0.95 \\
Bicarbonate & .12 & 2.70 & .03 \\
Calcium & .95 & .17 & .99 \\
Chloride & .93 & .30 & .99 \\
$\delta^{18} \mathrm{O}$ & 1.00 & .04 & .98 \\
$\delta^{2} \mathrm{H}$ & .86 & -14.00 & .84 \\
Magnesium & .90 & .23 & .97 \\
Nitrate & .44 & 19.00 & .45 \\
Potassium & .66 & .08 & .56 \\
Sodium & .37 & 1.61 & .44 \\
Sulfate & .97 & .06 & .98 \\
\hline
\end{tabular}

the upgradient side of the study site next to the wastewaterstorage lagoon. As much as 5 percent of water from the Terrace Farm was detected in three wells (MW-38, Terrace-2, and Terrace-3). All these wells were on the downgradient side of the wastewater-application area.

The $\delta^{15} \mathrm{~N}$ of nitrate generally ranged between +2 and +9 $\%$ and the $\delta^{18} \mathrm{O}$ of nitrate generally ranged between -2 and -6 $\%$ (table 1). Well MW-53, which represented the wastewater, had a $\delta^{15} \mathrm{~N}$ of $+2.36 \%$ and a $\delta^{18} \mathrm{O}$ of $-2.06 \%$. The measured isotope values at well MW-53 overlap with previously reported values for soil nitrogen $(\mathrm{N})$, animal and septic waste, and ammonium fertilizer (fig. 5). Values in this range generally are the result of nitrification. Isotope values resulting from nitrification of organic nitrogen in the food-processing wastewater determined in this study also are in this range.

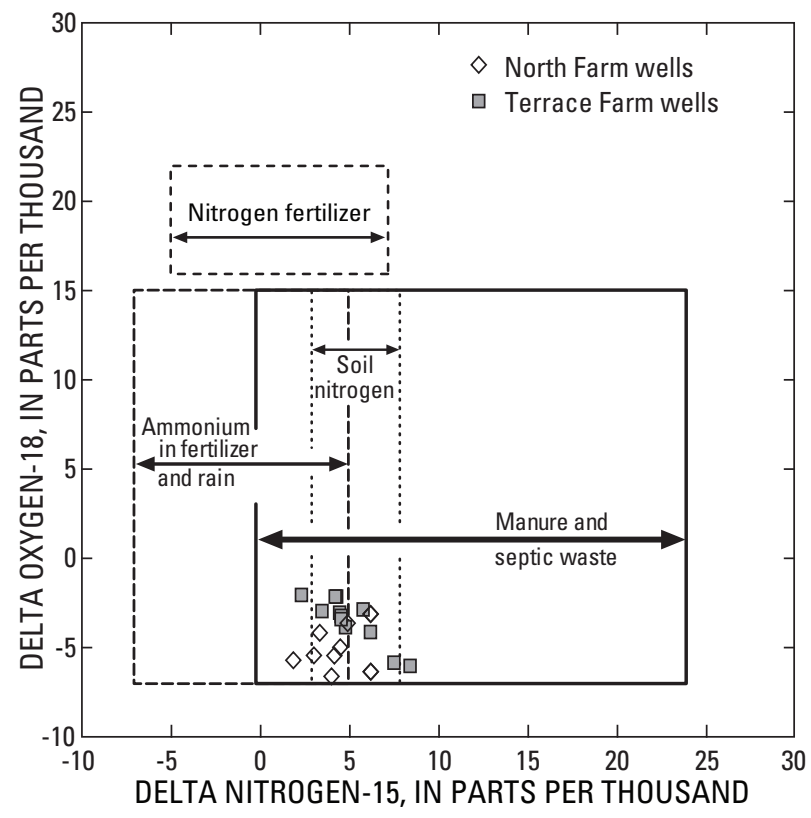

Figure 5. Ratios of delta oxygen-18 $\left(\delta^{18} 0\right)$ and delta nitrogen-15 $\left(\delta^{15} \mathrm{~N}\right)$ for nitrates in samples compared with the range of ratios expected for different sources of nitrate, Umatilla River basin, Oregon. (Ranges are from Kendall, 1998.) 
Because of the overlap in the potential nitrate sources, the proportion of each sample attributed to the Terrace Farm ground water was compared to the isotope values to determine any statistically significant relation (fig. 6). No significant relation was determined between either $\delta^{15} \mathrm{~N}$ or $\delta^{18} \mathrm{O}$ and the proportion of the Terrace Farm water ( $\boldsymbol{p}$-values $=0.68$ and 0.07 , respectively). For water samples from wells in the wastewater-application area with no Terrace Farm water, the nitrate-isotope values likely were primarily the result of ammonium fertilizer or nitrification of soil $\mathrm{N}$.
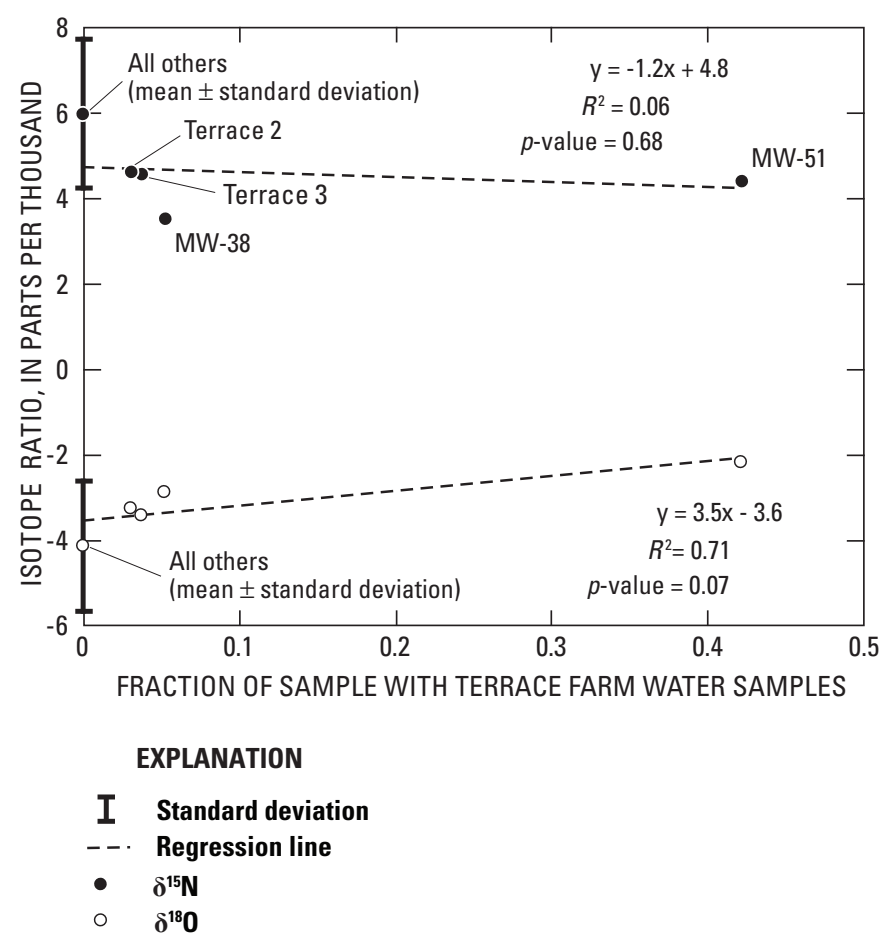

Figure 6. Relation between nitrate delta nitrogen-15 $\left(\delta^{15} \mathrm{~N}\right)$ and delta oxygen-18 $\left(\delta^{18} 0\right)$ isotope ratios and fraction of water samples from wells, Terrace Farm site, Umatilla River basin, Oregon.

\section{North Farm Site}

Interpretation of water-quality data from the North Farm site was more difficult than interpretation of water-quality data from the Terrace Farm site because the types and amounts of water applied to the North Farm site changed over time. From
1972 to 1992 , about 3.4 million $\mathrm{m}^{3}$ of process water were applied each year to the North Farm site with an additional $33,300 \mathrm{~m}^{3}$ of supplemental surface-water application. The alluvial wells at the wastewater-processing plant are the original sources of pre-processed water. Beginning in 1992, the amount of processed water applied annually to the North Farm wastewater-application site decreased to 284,000-370,000 $\mathrm{m}^{3}$ with an additional 1.4-1.9 million $\mathrm{m}^{3}$ of supplemental surface-water application (Emmett Walker, ConAgra Foods, oral commun., July 2006). Because the source of water has changed over time, application of the EMMA would not be appropriate at this site. Piper diagrams and constituent-constituent plots were examined to determine which wells, if any, were affected by the wastewater applications.

Ground-water levels collected at the North Farm wastewater-application site indicated that ground water flowed radially away from the center of the ground-water mound beneath the site with a southwesterly flow direction beneath the general study area (fig. 7A). Depths to water generally ranged from about $26 \mathrm{~m}$ on the edge of the wastewater application area to more than $45 \mathrm{~m}$ southwest of the Umatilla Ordnance Depot landfill (fig. 7B $)$. Unlike the water samples from wells collected at the Terrace Farm site, several samples collected downgradient of the North Farm site were below the local meteoric water line and may be affected by evaporation (fig. 3). Whether the evaporative signal of these samples was the result of changes to the ground water prior to pumpage and use in food processing or changes to the water after it was applied to the site is not known.

Wastewater applied at the North Farm site is particularly rich in potassium and sodium (fig. 8) compared with most of the ground-water samples. Wells MW-3, MW-4, MW-33, and 11-5 all appear to be affected by the processed water because they plot between the wastewater samples and remaining well samples as shown in figure 8.

Sulfate levels generally were low in the wastewater and supplemental surface-water irrigation (fig. 9). With the exception of samples from well MW-10, the samples clustered into two groups: (1) wells with low sulfate concentrations, which seemed to be affected by the wastewater, and (2) wells with high sulfate concentrations, which did not seem to be affected by the wastewater. Samples from wells 11-3, 11-4, 11-5, MW-3, MW-4, and MW-33 all had calcium and sulfate concentrations that were between those detected in the wastewater and those in the supplemental-irrigation water. 
A.

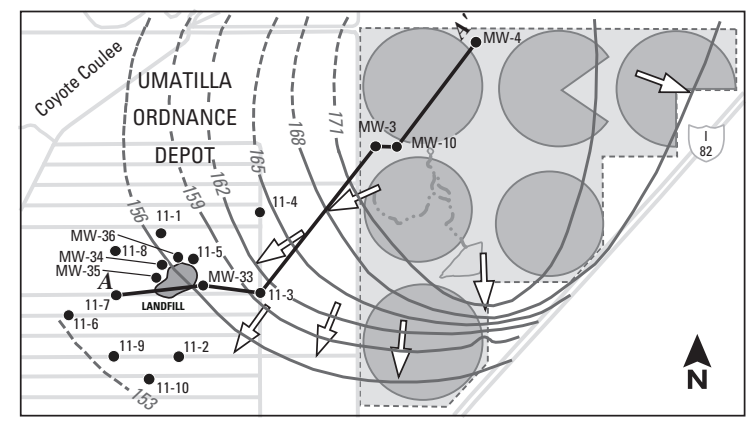

EXPLANATION

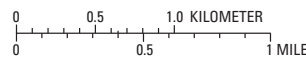

North Farm boundary

Land-application field

— 165 - Ground-water elevation contour Contour interval 3 meters dashed where uncertain

A $\quad A^{\prime}$ 'Transect

$<$ Ground-water flow direction Perpendicular to contours

$\bullet_{\mathrm{MW}-36}$ Sampled well location and No.

B.

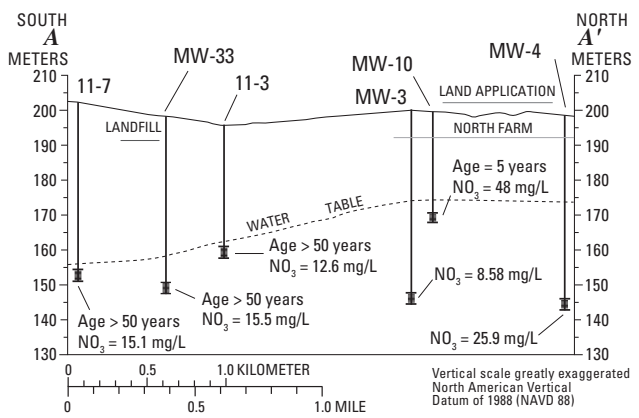

Figure 7. Locations of $(A)$ ground-water elevation contours and flow direction and $(B)$ depths to ground water, nitrate concentrations, and apparent recharge age at selected wells, North Farm site, Umatilla River basin, Oregon.

\section{EXPLANATION}

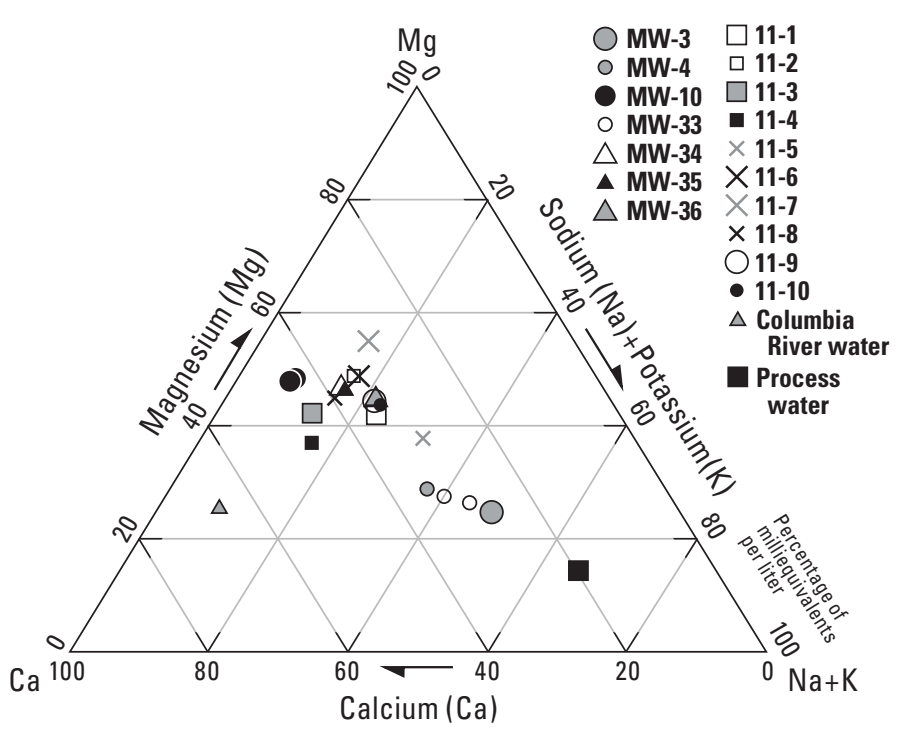

CATIONS

Figure 8. Trilinear diagram showing cations for North Farm site water samples from wells, Columbia River water, and process water from the wastewater-plant clarifier, Umatilla River basin, Oregon.

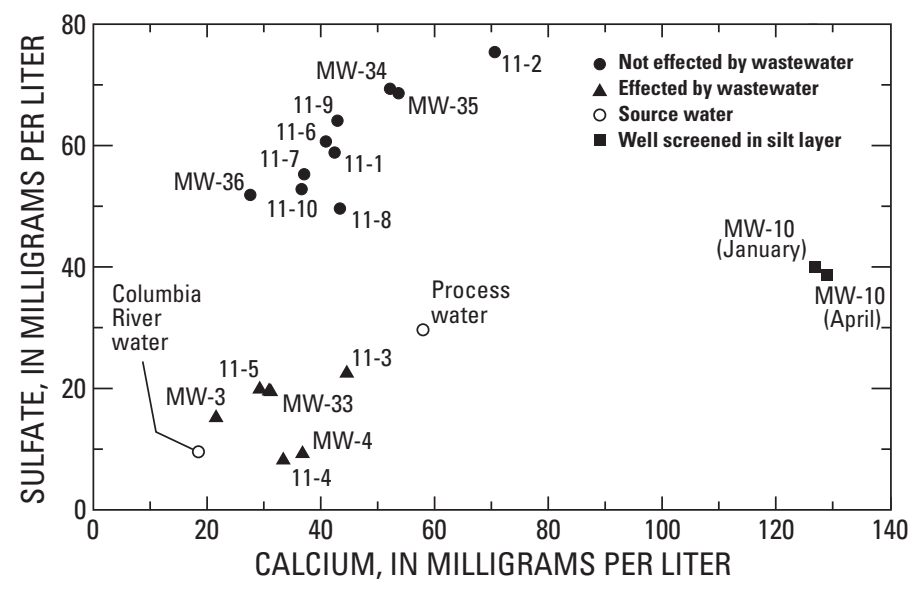

Figure 9. Relation of sulfate and calcium from water samples from wells at the North Farm site, Columbia River water, and process water from the wastewater-plant clarifier, Umatilla River basin, Oregon. 
Well MW-10 is on the edge of the wastewater-application area and is screened within a silt layer. Compared to wells affected by wastewater (low sulfate and high potassium), the water chemistry of this young water (5 years) from the shallow well MW-10 is perplexing. The highest concentrations of calcium, magnesium, alkalinity, chloride, and nitrate were detected in water from well MW-10 for the North Farm site, but potassium concentrations were within the range determined for wells affected by the wastewater. When compared to the wastewater affected wells, water from well MW-10 contained significantly more calcium, magnesium, alkalinity, and nitrate with lesser amounts of chloride and sulfate (table 4). The confinement of this water in the silt layer may have allowed geochemical reactions such as dissolution of gypsum and calcium-magnesium carbonates and the remineralization of total Kjeldahl nitrogen to nitrate to proceed faster relative to the flow of water. The addition of significant amounts of calcium, magnesium, and alkalinity shifted MW-10 water to a mixed-cation/bicarbonate type (fig. 8). Alternatively, water from MW-10 may reflect flow from surface-water irrigation applied north of the North Farm site.

The apparent-recharge age of the water just downgradient of the wastewater-application area in water samples from well MW-10 was 5 years. Further downgradient from the wastewater-application area, the apparent recharge dates of the three Umatilla Ordnance Depot wells, wells 11-3, 11-7, and MW-33, were greater than 50 years (table 1). The old apparent recharge age in these wells likely is because the source of most of the water applied to the North Farm site originally was ground water, which in this case appears to be tritium dead. The young age of the water in well MW-10 likely was due to surface-water irrigation either on the North Farm or the area north of the North Farm site. The lack of tritium in water samples from wells MW-33, 11-3, and 11-7 combined with $\delta^{18} \mathrm{O}$ and $\delta^{2} \mathrm{H}$ ratios of water below the local meteoric water line indicated that the water in these wells did not have a substantial amount of supplemental surface-water irrigation. The water in these wells likely was from the wastewater applied prior to 1992 when the supplemental surface water application amounts were less than 1 percent of the total water applied.

The $\delta^{15} \mathrm{~N}$ of nitrate in sampled wells generally ranged between +2 and $+6 \%$ and the $\delta^{18} \mathrm{O}$ of nitrate generally ranged between -3 and $-7 \%$ (fig. 10). The heaviest isotope values, with a $\delta^{15} \mathrm{~N}$ of $+6.27 \%$ and a $\delta^{18} \mathrm{O}$ of $-3.06 \%$, and the highest nitrate concentration were detected in the water sample collected from well MW-10. The samples from wells MW-3, MW-4, MW-33, 11-3, and 11-4, which are believed to be affected by the process water, also had slightly heavier values of $\delta^{18} \mathrm{O}$ than the remaining downgradient samples, but the values of $\delta^{15} \mathrm{~N}$ were similar. The samples affected by wastewater generally did not have distinctly different isotope values of nitrate when compared with samples that were not affected by wastewater. As at the Terrace Farm wastewaterapplication site, the measured isotope values at the North Farm wastewater-application site overlap with previously reported nitrate isotope values for soil $\mathrm{N}$, animal and septic waste, and ammonium fertilizer (Kendall, 1998) (fig. 5).

Table 4. Difference of cations and anions in water from well MW-10 compared to wells MW- $3,-4,-33$ and $11-3$ and -4 at the North Farm site, Umatilla River basin, Oregon.

\begin{tabular}{lc}
\hline \multicolumn{1}{c}{ Constituent } & $\begin{array}{c}\text { Difference } \\
\text { (millimolars) }\end{array}$ \\
\hline \multicolumn{2}{c}{ Cations } \\
\hline Calcium & \\
Magnesium & 2.37 \\
Potassium & 2.79 \\
Sodium & -.00 \\
$\quad$ Total milliequivalents & -.41 \\
\hline \multicolumn{2}{c}{ Anions } \\
Alkanity & 9.91 \\
Chloride & \\
Sulfate & 5.50 \\
Nitrate & 1.31 \\
$\quad$ Total milliequivalents & .25 \\
\hline
\end{tabular}

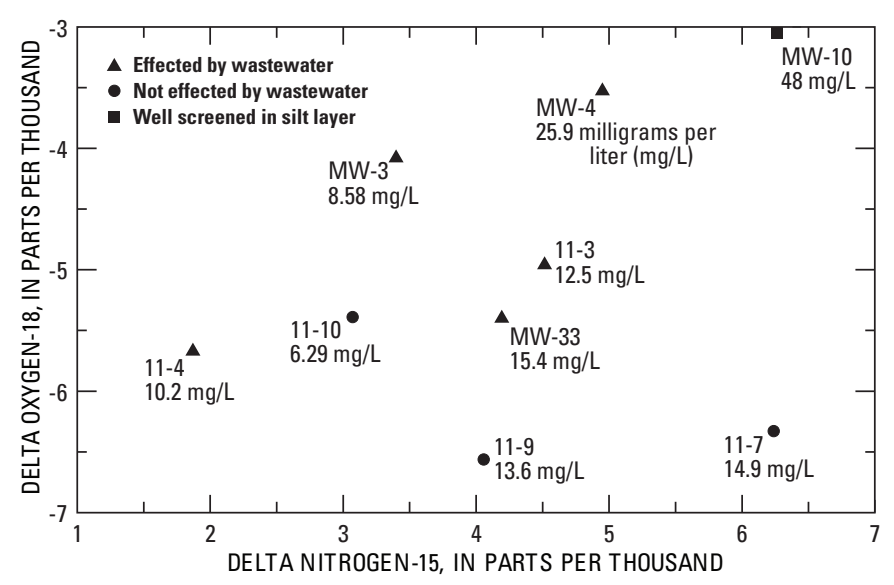

Figure 10. Relations between delta oxygen-18 $\left(\delta^{18} 0\right)$ and delta nitrogen-15 $\left(\delta^{15} \mathrm{~N}\right)$ of nitrate from water samples from wells, North Farm site, Umatilla River basin, Oregon. (Symbols are labeled with the nitrate concentration of each sample.) 


\section{Summary}

End-member mixing analysis (EMMA) was used to determine the relative mixing amounts of water samples collected from wells at the Terrace Farm site and was robust in predicting the concentrations of the conservative solutes. The relative proportions of each end member were not inconsistent with the hydrogeologic setting. Nitrate and several other major ions (potassium and sodium), however, did not appear to be conservative.

Piper diagrams and constituent-constituent plots were used to determine which samples were affected by the wastewater at the North Farm application site.

The delta nitrogen-15 $\left(\delta^{15} \mathrm{~N}\right)$ of nitrate generally ranged between +2 and +9 parts per thousand and the delta oxygen-18 $\left(\delta^{18} \mathrm{O}\right)$ of nitrate generally ranged between -2 and -7 parts per thousand. No relation was determined between $\delta^{15} \mathrm{~N}$ and $\delta^{18} \mathrm{O}$ values and the proportion of a sample attributed to food-processing wastewater at the Terrace Farm application site. Additionally, no differences in nitrate-isotope values were detected between samples affected by the wastewater at the North Farm application site and samples that were not affected by the wastewater. These observations indicated that the nitrate derived from the food-processing wastewater likely was not distinct from other nitrate, because it overlaps with nitrate from ammonium fertilizer, animal and septic waste, and soil nitrogen. Values of $\delta^{15} \mathrm{~N}$ and $\delta^{18} \mathrm{O}$ of nitrate provided no additional information about sources of nitrate in the Umatilla River basin than did a hydrologic and geochemical understanding of the ground-water system derived from interpreting water-level and major-ion chemistry data.

\section{References Cited}

Amberger, A., and Schmidt, H.L., 1987, Natural isotope contents of nitrate as indicators of its origin: Geochimica et Cosmochimica Acta, no.10, v. 51, p. 2699-2705.

Aravena, R., Evans, M.L., and Cherry, J.A., 1993, Stable isotopes of oxygen and nitrogen in source identification of nitrate from septic systems: Ground Water, v. 31, p. $180-186$.

Aravena, R., and Robertson, W.D., 1998, Use of multiple isotope tracers to evaluate denitrification in groundwater: Case study of nitrate from a large-flux septic system plume: Ground Water, v. 36, no. 6, p. 975-982.

Böhlke, J.K., Mroczkowski, S.J., and Coplen, T.B., 2004, New reference materials for oxygen isotopes in nitrate-Isotope hydrology and integrated water resources management: Vienna, Austria, International Atomic Energy Agency, p. $477-478$.
Casciotti, K.L., Sigman, D.M., Galanter Hastings, M., Böhlke, J.K., and Hilkert, A., 2002, Measurement of the oxygen isotopic composition of nitrate in seawater and freshwater using the denitrifier method: Analytical Chemistry, v. 74, p. 4905-4912.

Christophersen, Nils, and Hooper, Richard, 1992, Multivariate analysis of stream water chemical data: The use of principal components analysis for the end-member mixing problem: Water Resources Research, v. 28, no. 1, p 99-107.

Clark, Ian, and Fritz, Peter, 1997, Environmental isotopes in hydrogeology: Boca Raton, Fla., CRC Press LLC, 328 p.

Coplen, T.B., 1996, New guidelines for the reporting of stable hydrogen, carbon, and oxygen isotope ratio data: Geochimica et Cosmochimica Acta, v. 60, p. 3359.

Coplen, T.B., Wildman, J.D., and Chen, Julie, 1991, Improvements in the gaseous hydrogen-water equilibration technique for hydrogen isotope ratio analysis: Analytical Chemistry, v. 63, p. 910-912.

Ekwurzel, Brenda, Schlosser, Peter, Smethie, William Jr., Plummer, L.N., Busenburg, Eurybiades, Michel, R.L., Weppernig, Ralf, and, Stute, Martin, 1994, Dating of shallow groundwater: Comparison of the transient tracers ${ }^{3} \mathrm{H} /{ }^{3} \mathrm{He}$, chlorofluorocarbons and ${ }^{85} \mathrm{Kr}$ : Water Resources Research, v. 30, no. 6, p. 1693-1708.

Epstein, Samuel, and Mayeda, Toshiko, 1953, Variation of ${ }^{18} \mathrm{O}$ content of water from natural sources: Geochimica Cosmochimica Acta, v. 4, p. 213-224.

Exner, M.E., and Spalding, R.E, 1985, Ground-water contamination and well construction in southeast Nebraska: Ground Water, v. 23, p. 26-34.

Flipse, W.J., Jr., and Bonner, E.T., 1985, N-isotope ratios in ground water under fertilized fields, Long Island, New York: Ground Water, v. 23, p. 59-67.

Flipse, W.J. Jr., Katz, B.G., Lidner, J.B., and Markel, R., 1984, Sources of nitrate in ground water in a sewered housing development, central Long Island, New York: Ground Water, v. 22, p. 418-426.

Gormly, J.R., and Spalding, R.E., 1979, Sources and concentrations of nitrate-N in ground water of the central Platte region, Nebraska: Ground Water, v. 17, p. 291-301.

Grondin, G.H., and Camacho, I., 1995, Land use and nitrogen loading in the Lower Umatilla Basin Groundwater Management area, in Grondin, G.H., Wozniak, K.C., Nelson, D.O., and Camacho, I., Hydrogeology, groundwater chemistry and land uses in the Lower Umatilla basin groundwater management area: Pendleton, Oreg., Oregon Department of Environmental Quality, misc. pagination. 
Grondin, G.H., and Nelson, D.O., 1995, Groundwater chemistry, in Grondin, G.H., Wozniak, K.C., Nelson, D.O., and Camacho, I., Hydrogeology, groundwater chemistry and land uses in the Lower Umatilla basin groundwater management area: Pendleton, Oreg., Oregon Department of Environmental Quality, misc. pagination.

Heaton, T.H.E., 1984, Sources of the nitrate in phreatic groundwater in the western Kalahari: Journal of Hydrology, v. 67 , p. $249-259$.

Heaton, T.H.E., 1986, Isotopic studies of nitrogen pollution in the hydrosphere and atmosphere-A review: Chemical Geology, v. 59, p. 87-102.

Heaton, T.H.E., Talma, A.S., and Vogel, J.C., 1983, Origin and history of nitrate in confined groundwater in the western Kalahari: Journal of Hydrology, v. 62, p. 243-262.

Hubner, H., 1986, Isotope effects of nitrogen in the soil and biosphere, in Fritz, P., and Fontes, J., eds., Handbook of environmental isotope geochemistry, v. 2b, The terrestrial environment: The Netherlands, Elsevier, p. 361-425.

Kendall, Carol, 1998. Tracing nitrogen sources and cycling in catchments, in Kendall, Carol, and McDonnell, J.J., eds., Isotope-tracers in catchment hydrology: The Netherlands, Elsevier, p. 534-569.

Kohl, D.H., Shearer, G.B., and Commoner, B., 1971, Fertilizer nitrogen-Contribution to nitrate in surface water in a corn belt watershed: Science, v. 174, p. 1331-1334.

Komor, S.C., and Anderson, H.W., Jr., 1993, Nitrogen isotopes as indicators of nitrate sources in Minnesota sand-plain aquifers: Ground Water, v. 31, p. 260-270.

Kreitler, C.W., 1975, Determining the sources of nitrate in ground water by nitrogen isotope studies: Austin, University of Texas, Bureau of Economic Geology, Report of Investigations No. 83, $57 \mathrm{p}$.

Kreitler, C.W., 1979, Nitrogen-isotope ratio studies of soils and groundwater nitrate from alluvial fan aquifers in Texas: Journal of Hydrology, v. 42, p. 147-170.

Kreitler, C.W., and Browning, L.A., 1983, Nitrogen-isotope analysis of groundwater nitrate in carbonate aquifersNatural sources versus human pollution: Journal of Hydrology, v. 61, p. 285-301.

Kreitler, C.W., and Jones, D.C., 1975, Natural soil nitrateThe cause of the nitrate contamination of ground water in Runnels County, Texas: Ground Water, v. 13, p. 53-61.
Kreitler, C.W., Ragone, S.E., and Katz, B.G., 1978, N15/N $\mathrm{N}^{14}$ ratios of ground-water nitrate, Long Island, New York: Ground Water, v. 16, p. 404-409.

Ludin, A., Weppernig, R., Bonisch, G., and Schlosser, P., 1998, Mass spectrometric measurement of helium isotopes and tritium in water samples: Palisades, NY, LamontDoherty Earth Observatory, Columbia University, Technical Report 98.6, accessed 1/20/2005, at http://www.ldeo. columbia.edu/-noblegas/ms_rns/Ludin et al MS_Paper.html

Mariotti, A., 1983, Atmospheric nitrogen is a reliable standard for natural ${ }^{15} \mathrm{~N}$ abundance measurements: Nature, v. 303, p. 685-687.

Mariotti, Andre, Lancelot, Christiane, and Billen, Gilles, 1984, Natural isotopic composition of nitrogen as a tracer of origin for suspended organic matter in the Scheldt estuary: Geochimica et Cosmochimica Acta, v. 48, p. 549-555.

Mariotti, Andre, Landreau, Alain, and Simon, Beatrice, 1988, ${ }^{15} \mathrm{~N}$ isotope biogeochemistry and natural denitrification process in groundwater-Application to the chalk aquifer of northern France: Geochimica et Cosmochimica Acta, v. 52, p. $1869-1878$.

Mariotti, Andre, Pierre, D., Vedy, J.C., Bruckert, S., and Guillemot, J., 1980, The abundance of natural nitrogen-15 in the organic matter of soils along an altitudinal gradient: Catena, v. 7, p. 293-300.

Revesz, Kinga, and Casciotti, Karen., 2007, Determination of the $\delta\left({ }^{15} \mathrm{~N} /{ }^{14} \mathrm{~N}\right)$ and $\delta\left({ }^{18} \mathrm{O} /{ }^{16} \mathrm{O}\right)$ nitrate in water-RSIL Lab Code 2900: U.S. Geological Survey Techniques and Methods 10-C17, chap. 17, sec. C, book 10, 24 p.

Richerson, P., 2004, Trend analysis of food processor land application sites in the Lower Umatilla Basin Groundwater Management Area: Pendleton, Oreg., Oregon Department of Environmental Quality, misc. pagination.

SAS Institute, 1990, SAS/STAT user's guide: Cary, N.C., SAS Institute, Inc., 1,686 p.

Schlosser P., Stute, M., Dorr, H., Sonntag, C., and Munnich, K.O., 1988, Tritium $/{ }^{\beta} \mathrm{He}$ dating of shallow groundwater: Earth and Planetary Science Letters, v. 89, p. 353-362.

Schlosser P., Stute, M., Sonntag, C., and Munnich, K.O., 1989, Tritiogenic ${ }^{3} \mathrm{He}$ in shallow groundwater: Earth and Planetary Science Letters, v. 94, p. 245-256.

Sigman, D.M., Casciotti, K.L., Andreani, M., Barford, C., Galanter, M., and Böhlke, J.K., 2001, A bacterial method for the nitrogen isotopic analysis of nitrate in seawater and freshwater: Analytical Chemistry, v. 73, p. 4145-4153. 
Spalding, R.E., Exner, M.E., Lindau, C.W., and Eaton, D.W., 1982, Investigation of sources of groundwater nitrate contamination in the Burbank-Wallula area of Washington, U.S.A.: Journal of Hydrology, v. 58, p. 307-324.

U.S. Environmental Protection Agency, 1991, Methods for the determination of metals in environmental samples: Cincinnati, Ohio, U.S. Environmental Protection Agency, EPA/600/4-91/010, misc. pagination.

U.S. Environmental Protection Agency, 1993, Methods of determination of inorganic substances in environmental samples: Cincinnati, Ohio, U.S. Environmental Protection Agency, EPA/600/R-93/100, misc. pagination.
Wolterink, T.J., Williamson, H.J., Jones, D.C., Grimshaw, T.W., and Holland, W.F., 1979, Identifying sources of subsurface nitrate pollution with stable nitrogen isotopes: U.S. Environmental Protection Agency, EPA-600/4-79-050, $150 \mathrm{p}$.

Wozniak, K.C., 1995, Hydrogeology, in Grondin, G.H., Wozniak, K.C., Nelson, D.O., and Camacho, I., Hydrogeology, groundwater chemistry and land uses in the Lower Umatilla basin groundwater management area: Pendelton, Oreg., Oregon Department of Environmental Quality, misc. pagination. 
This page intentionally left blank. 
Publishing support provided by the U.S. Geological Survey Publishing Network, Tacoma Publishing Service Center

For more information concerning the research in this report, contact the Director, Washington Water Science Center

U.S. Geological Survey, 934 Broadway - Suite 300

Tacoma, Washington 98402

http://wa.water.usgs.gov 
产

옹

๕

운

글

萬

苋

홈

궁

密.

ริำ



蛋

궁

흏

离

옥

돌

จ

옹

ธิ

兽 